University of Nebraska - Lincoln

DigitalCommons@University of Nebraska - Lincoln

Agronomy \& Horticulture -- Faculty Publications

Agronomy and Horticulture Department

2007

\title{
Corn-Velvetleaf (Abutilon theophrasti) Interference Is Affected by Sublethal Doses of Postemergence Herbicides
}

Brescia R. M. Terra

Du Pont do Brasil S.A.

Alexander R. Martin

University of Nebraska-Lincoln

John L. Lindquist

University of Nebraska-Lincoln, jlindquist1@unl.edu

Follow this and additional works at: https://digitalcommons.unl.edu/agronomyfacpub

Part of the Plant Sciences Commons

Terra, Brescia R. M.; Martin, Alexander R.; and Lindquist, John L., "Corn-Velvetleaf (Abutilon theophrasti) Interference Is Affected by Sublethal Doses of Postemergence Herbicides" (2007). Agronomy \& Horticulture -- Faculty Publications. 373.

https://digitalcommons.unl.edu/agronomyfacpub/373

This Article is brought to you for free and open access by the Agronomy and Horticulture Department at DigitalCommons@University of Nebraska - Lincoln. It has been accepted for inclusion in Agronomy \& Horticulture -Faculty Publications by an authorized administrator of DigitalCommons@University of Nebraska - Lincoln. 


\title{
Corn-Velvetleaf (Abutilon theophrasti) Interference Is Affected by Sublethal Doses of Postemergence Herbicides
}

\author{
Brescia R. M. Terra, Alexander R. Martin, and John L. Lindquist*
}

\begin{abstract}
Injury to weeds from sublethal doses of POST herbicides may reduce the effect of weed interference on crop yield. Information on how herbicide dose influences weed mortality, growth, and seed production is needed to assess the potential benefit of applying reduced herbicide doses. Field experiments were conducted at Mead, NE, in 2001 and 2002 to quantify velvetleaf mortality, growth, and corn-velvetleaf interference in response to varying doses of three POST herbicides. Untreated velvetleaf at six densities $\left(0,1,3,6,12\right.$, and 20 plants $\mathrm{m}^{-1}$ corn row) was grown in mixture with corn to establish a baseline corn-velvetleaf interference relationship. Treated velvetleaf at a density of 20 plants $\mathrm{m}^{-1}$ row received one of five doses of dicamba, halosulfuron, or flumiclorac. Untreated velvetleaf height, biomass, and seed capsule production were greater in 2002 than 2001 and declined with increasing velvetleaf density in both years. Corn yield was not affected by untreated velvetleaf in 2001, but yield loss increased with increasing velvetleaf density in 2002. Mortality of herbicide-treated velvetleaf was 56\% greater in 2001 than 2002 and increased with increasing herbicide dose. Maximum height of treated velvetleaf was similar for all treatments in 2001 but declined with increasing herbicide dose in 2002. Biomass and seed production of treated velvetleaf varied among herbicides in 2002 and decreased with increasing dose. Corn yield was not influenced by velvetleaf in 2001, but yield loss in response to herbicide-treated velvetleaf declined with increasing herbicide dose in 2002. Results show that the assumption that weeds surviving herbicide application are as competitive as untreated weeds is incorrect. Reduction in growth and resource consumption by herbicide-damaged weeds reduced the negative effects of weeds on corn.
\end{abstract}

Nomenclature: Dicamba; halosulfuron; flumiclorac; velvetleaf, Abutilon theophrasti Medic. ABUTH; corn, Zea mays L. Key words: Efficacy, reduced rate, dose response, competition, weed escape.

Velvetleaf is an annual broadleaf species native to China, where it was cultivated as a fiber crop (Sattin et al. 1992). Velvetleaf likely arrived in North America in the 17th century and was widespread throughout the colonies, but attempts to process velvetleaf fiber never succeeded because of its inferior fiber characteristics and lack of suitable machinery (DeFelice et al. 1989). Velvetleaf is one of the most troublesome weeds in the northcentral United States (Bridges 1992). The importance of velvetleaf as a weed in corn has increased over time, partly because it is relatively tolerant to many herbicides (Liphadzi and Dille 2006).

Velvetleaf growing without competition may produce up to 17,000 seeds plant ${ }^{-1}$ (Warwick and Black 1988). Plants growing in competition with corn produced 720 to 2,200 seeds plant ${ }^{-1}$ (Clay et al. 2005). Seeds are characterized by high viability and longevity (Hartzler and Battles 2001), contributing to its long-term success. If velvetleaf and corn emerge simultaneously, velvetleaf can surpass corn growth by the end of the season, develop a layer of leaves above the corn canopy and, therefore, interfere with crop light interception (Sattin et al. 1992).

Lindquist et al. (1998) argued that velvetleaf competes primarily for light in most corn production systems. Moreover, velvetleaf leaves are both nyctinastic and heliotropic (Koide and Schreiner 1994), which results in a solid shadow under the weed canopy. Consequently, corn net assimilation rate during flowering and grain filling is reduced, which ultimately results in reduced grain yield (Sattin et al. 1992). Velvetleaf can reduce corn yield by as little as $0 \%$ to as much as $80 \%$ depending on the environment in which it occurs (Lindquist et al. 1996).

\footnotetext{
DOI: 10.1614 /WS-06-140.1

* First author: Du Pont do Brasil S.A., Divisao Pioneer Sementes, Santa Cruz do Sul, RS 96810-971, Brazil; second and third authors: Department of Agronomy and Horticulture, University of Nebraska, Lincoln, NE 68583-0915; Corresponding author's E-mail: jlindquist1@unl.edu
}

Weed control to reduce competitive losses has always been a priority of agricultural producers. Herbicides have been the preferred method of weed control for more than $50 \mathrm{yr}$ (Liphadzi and Dille 2006). However, increasing herbicide costs have contributed to declining profit margins (Liebman et al. 2001). In addition to increasing costs, concerns about pesticide residues in food, environmental contamination, ground and surface water quality, reducing herbicide carryover, development of herbicide-resistant weed populations, and health hazards have resulted in research directed at reducing our reliance on herbicides.

Recommended labeled doses of herbicides are often greater than necessary for effective weed control (Dieleman et al. 1996). Manufacturers usually prescribe large dosages to ensure effective weed control over a broad range of species, management, and environmental conditions (Devlin et al. 1991). Although any risk associated with use of reduced doses, such as reduced efficacy or uncontrolled species, is assumed by the grower (Dieleman and Mortensen 1998), one way to achieve reduced reliance on herbicides is to adjust the herbicide dose to the lowest effective dose for a given species and environment (Dieleman and Mortensen 1998; Dieleman et al. 1996). Better understanding of weed response to varying herbicide dose is needed to effectively implement such a strategy.

Weed management decision support systems (DSS) are an effective tool to integrate and process large quantities of information and aid in selecting appropriate management options (Martin et al. 1998). WeedSOFT ${ }^{1}$ is a computerbased DSS developed to assist producers and managers in making weed management decisions (Neeser et al. 2004). WeedSOFT and other DSSs account for the influence of weed density and size on crop yield loss before and after application of the herbicide. Unfortunately, they assume weeds that survive a herbicide treatment are as competitive as untreated weeds. The result is an overestimation of yield loss, which consequently will increase the recommended herbicide dose 
(Lindquist and Knezevic 2001; Liphadzi and Dille 2006). Accurate information on the growth, fecundity, and cropweed interference effects of weeds that survive herbicide treatment will help to provide output that is more realistic from DSSs. Therefore, the objectives of this research were to quantify mortality, growth, and seed capsule production of velvetleaf treated with varying doses of three common POST herbicides and to determine whether surviving velvetleaf are as competitive with corn as untreated velvetleaf.

\section{Materials and Methods}

Experimental Design. Field experiments were conducted in 2001 and 2002 at the University of Nebraska Agricultural Research and Development Center (ARDC) near Mead, NE $\left(41^{\circ} 10^{\prime} \mathrm{N}, 96^{\circ} 24^{\prime} \mathrm{W} ; 355 \mathrm{~m}\right.$ above sea level). Soil type was a Sharpsburg silty clay loam (fine, smectitic, mesic Typic Argiudoll) with 0 to $2 \%$ slope, $\mathrm{pH} 6.7$ to 6.8 , and $3.3 \%$ soil organic matter in both years. The experimental fields were planted to soybean [Glycine max (L.) Merr.] in the year before establishment. Each year of the experiment, primary tillage consisted of moldboard plow in the fall and one field cultivation before planting. Nitrogen at $140 \mathrm{~kg} \mathrm{~N} \mathrm{ha}^{-1}$ as anhydrous ammonia was applied $1 \mathrm{wk}$ before planting in 2001 and at $160 \mathrm{~kg} \mathrm{~N} \mathrm{ha}^{-1} 1$ mo before planting in 2002 .

Corn hybrid 'Pioneer 33A14' was seeded in rows spaced $0.76 \mathrm{~m}$ apart at a density of 64,000 seeds $\mathrm{ha}^{-1}$ on May 1 , 2001, and 58,000 seeds ha ${ }^{-1}$ on May 8, 2002. In both years, alachlor at $1.06 \mathrm{~kg}$ ai ha ${ }^{-1}$ was applied PRE after planting to control grass weeds. Velvetleaf was seeded $1 \mathrm{~cm}$ deep directly into each corn row using a push planter on May 7, 2001, and May 9, 2002, and thinned to target densities after seedlings reached $2 \mathrm{~cm}$. Other weeds were controlled manually as needed. Corn emerged on May 12, 2001, and May 17, 2002, and velvetleaf emerged on May 14, 2001, and May 17, 2002. Irrigation was provided only in 2002, starting from June 26, with approximately $38 \mathrm{~mm}$ of water applied weekly.

Experimental design was a randomized complete block with four replicates. Each block had 21 experimental units (plots) measuring four rows wide by $9 \mathrm{~m}$ long. Six plots in each block were herbicide-free with varying velvetleaf densities $(0,1,3,6$, 12 , and 20 plants $\mathrm{m}^{-1}$ row) to evaluate the effects of weed density on velvetleaf growth and corn yield in absence of herbicide treatment. The remaining 15 plots in each block were treated with three POST herbicides at five doses, all with an initial velvetleaf density of 20 plants $\mathrm{m}^{-1}$ row. This set of treatments was used to measure velvetleaf mortality, the subsequent effects of each herbicide on growth of surviving velvetleaf plants, and the influence of those plants on corn yield.

The three herbicides, registered for corn and recommended for velvetleaf control, had different modes of action to obtain a range of physiological and morphological responses. The herbicides were dicamba, an auxin-like growth regulator; halosulfuron, an amino acid biosynthesis inhibitor; and flumiclorac, a cell membrane disrupter. Application doses were $0.10,0.25,0.50,0.75$, and 1.0 times the labeled dose. Labeled doses were dicamba at $318 \mathrm{~g}$ ae ha ${ }^{-1}$, halosulfuron at $36 \mathrm{~g}$ i ha ${ }^{-1}$, and flumiclorac at $3 \mathrm{~g}$ ai ha ${ }^{-1}$.

Herbicides were band-applied on June 20, 2001, and June 6,2002 , when velvetleaf plants were approximately $4 \mathrm{~cm}$ tall and had two to four leaves. A $\mathrm{CO}_{2}$-pressurized backpack sprayer was used to apply the herbicide in 2001 , and a tractor-
Table 1. Monthly rainfall and mean daily temperatures at the University of Nebraska Agricultural Research and Development Center during the 2001 and 2002 growing seasons and the 30-yr averages.

\begin{tabular}{|c|c|c|c|c|c|c|}
\hline \multirow[b]{2}{*}{ Month } & \multicolumn{2}{|c|}{ Rainfall } & \multicolumn{2}{|c|}{ Temperature } & \multicolumn{2}{|c|}{ 30-yr. average } \\
\hline & 2001 & 2002 & 2001 & 2002 & Rainfall & Temperature \\
\hline & - & & {[} & & $\mathrm{mm}$ & $\mathrm{C}$ \\
\hline April & 46 & 69 & 12.5 & 11.1 & 87 & 10.5 \\
\hline May & 230 & 75 & 17.3 & 15.2 & 109 & 17.4 \\
\hline June & 40 & 20 & 21.8 & 24.9 & 129 & 21.4 \\
\hline July & 25 & 31 & 25.9 & 26.9 & 75 & 25.0 \\
\hline August & 79 & 167 & 24.0 & 23.6 & 74 & 23.4 \\
\hline September & 67 & 36 & 18.1 & 19.4 & 60 & 18.3 \\
\hline Total & 487 & 398 & & & 534 & \\
\hline
\end{tabular}

mounted sprayer was used in 2002. Flat fan 110015 nozzles $^{2}$ were used with a sprayer pressure of $207 \mathrm{kPa}$ and a carrier volume of $140 \mathrm{~L} \mathrm{ha}^{-1}$ in both years.

Velvetleaf density counts were taken each week in 2001 and every other week in 2002 using the two middle rows of each plot. Velvetleaf canopy height was measured from the soil surface to the top of the same 10 plants every week in both years. Those 10 velvetleaf plants were harvested on October 15, 2001, and September 17, 2002, by clipping plants at the soil surface. Number of capsules plant ${ }^{-1}$ was recorded and plants were dried at $60 \mathrm{C}$ to constant weight to determine weed biomass $\left(\mathrm{g}\right.$ plant $\left.{ }^{-1}\right)$.

Corn yield was determined on October 29, 2001, and September 20, 2002, by hand-harvesting ears from the two middle rows of each experimental unit. Ears were shelled and moisture content was recorded. All yields are presented on a $15.5 \%$ moisture basis. Daily weather data were obtained through the High Plains Climate Center from an automated weather station within $1 \mathrm{~km}$ of the experimental field. Monthly averages of mean temperature and precipitation are reported in Table 1.

Data Analysis. Velvetleaf mortality was calculated as (first count - second count)/first count, where first count was the number of plants row ${ }^{-1}$ before the herbicide application and second count was the smallest number of plants row ${ }^{-1}$ counted during the season. Velvetleaf mortality, growth, seed production, and corn-velvetleaf interference data were analyzed separately for untreated (response to initial velvetleaf density) and treated plots (response to herbicide and dose). However, the untreated velvetleaf at 20 plants $\mathrm{m}^{-1}$ row was used as the 0 dose control in the analysis of treated plots. All variables were subjected to an overall ANOVA using SAS PROC MIXED ${ }^{3}$ to test for differences across initial density or herbicide and dose treatments, and for treatment-by-year interactions. Year and year-by-treatment effects were usually significant, so data were analyzed and reported separately by year. Replication within year was treated as a random effect. Comparison among initial velvetleaf density and herbicide and dose treatments were made at $\alpha=0.05$ (Littell et al. 1996).

Corn yield loss was calculated as $1-\left(Y_{t r t} / Y_{w f}\right)$ where $Y_{w f}$ was average yield in weed-free plots and $Y_{t r t}$ the yield within a given treatment. Corn yield loss resulting from untreated velvetleaf was regressed on initial velvetleaf density using (Cousens 1985)

$$
Y_{L}=I N /(1+I N / A)
$$


where $Y_{L}$ is percentage yield loss, $N$ is weed density, $I$ is the slope of the relationship as velvetleaf density approaches zero, and $A$ is the asymptote or percentage yield loss as velvetleaf density approaches infinity. Corn yield in monoculture and in mixture with herbicide-treated velvetleaf was compared among herbicide and dose treatments using ANOVA. Yield loss in 2002 resulting from herbicide-treated velvetleaf interference was compared with yield loss expected based on Equation 1 above using a chi-square test (Devore and Peck 1986).

\section{Results and Discussion}

Velvetleaf Mortality. Mortality of untreated velvetleaf increased with increasing velvetleaf initial density and was greater in 2001 than 2002 (Figure 1). Plants that grew at the lowest density ( 1 plant $\mathrm{m}^{-1}$ row) had approximately $20 \%$ mortality in both years, whereas mortality in the highest density treatments was 66\% in 2001 and $44 \%$ in 2002 .

Differences in growing conditions may have contributed to variation in mortality among years. Velvetleaf emergence in 2001 occurred $2 \mathrm{~d}$ after corn emergence, but emergence was simultaneous in 2002. Precipitation in May 2001 and 2002 was 211 and $69 \%$ of the $30-y r$ average, respectively (Table 1). However, the June and July precipitation accumulations were only 32 and $25 \%$ of the 30-yr average in 2001 and 2002, respectively. Although 2002 was drier, water was supplied through irrigation from June 26 until the end of the season, whereas the experiment was not irrigated in 2001. Rainfall at the beginning of summer 2001 provided enough water for velvetleaf germination, but dry conditions in June and July along with the delayed emergence may have caused the greater observed velvetleaf mortality in 2001 .

Withering of leaves and death of velvetleaf seedlings were observed in 2001. Moist conditions like those in May 2001 are ideal for the development of fungal pathogens such as Verticillium and Fusarium, both of which affect velvetleaf (Kremer and Schulte 1989; Sickinger et al. 1987). Fungal spores can survive the winter and infest susceptible plants when environmental conditions become favorable. Experimental plots in 2001 were located in a field used for velvetleaf research for about $6 \mathrm{yr}$, whereas the adjacent 2002 field did not have a long history of velvetleaf presence. Wilting of velvetleaf plants was not observed in 2002. Therefore, it is possible that a negative feedback effect (Klirinomos 2002) was occurring in the field in 2001.

Herbicide-treated velvetleaf mortality in 2001 was always greater than untreated velvetleaf mortality (66\%; Figure 1). Velvetleaf mortality in 2001 varied among herbicide type but

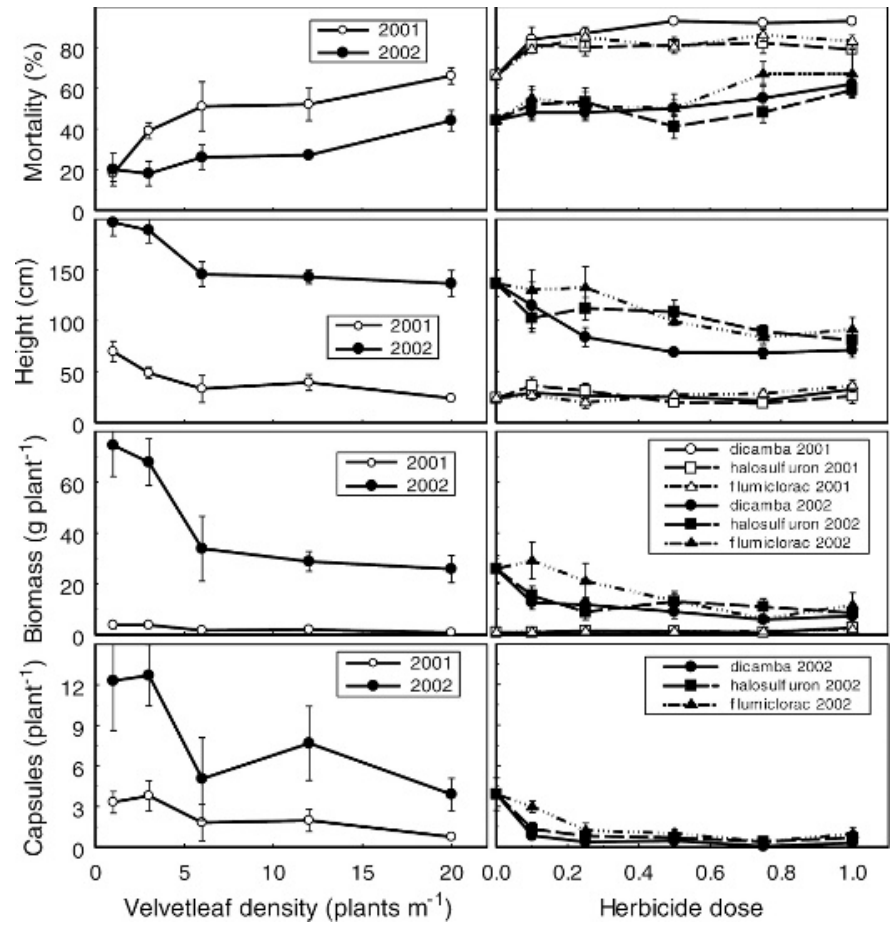

Figure 1. Velvetleaf response to initial velvetleaf density without herbicide treatment (left panels) and to three POST herbicides applied to 20 plants $\mathrm{m}^{-1}$ row at five doses (fraction of the labeled rate; right panels) in 2001 and 2002. Bars represent standard error of the mean.

not across herbicide dose (Table 2). Velvetleaf mortality in 2001 resulting from treatment with halosulfuron $(80 \%)$ did not differ from that by flumiclorac $(83 \%)$, but dicamba resulted in the greatest mortality $(90 \%)$.

Velvetleaf mortality in 2002 varied among herbicide and dose treatments but not their interaction (Table 2). Mortality in 2002 did not differ between the dicamba (53\%) and halosulfuron $(51 \%)$ treatments but was greatest $(58 \%)$ from flumiclorac across all dose treatments. Mortality generally increased with increasing herbicide dose (Figure 1). In 2002, only treatments with flumiclorac at 0.75 and 1.0 doses caused higher mortality than untreated velvetleaf (at 20 plants $\mathrm{m}^{-1}$ row). These results are similar to those of Murphy and Lindquist (2002), who found that only flumiclorac at $50 \%$ of the full dose and halosulfuron at the full dose produced greater mortality than control plots. These results may be because of a high capacity of velvetleaf to resume growth when treated tissues are not killed rapidly by these herbicides.

Table 2. Statistical significance levels for the effects of untreated velvetleaf density or treatment with herbicide and dose on velvetleaf mortality, maximum observed height, biomass $\left(\mathrm{g}\right.$ plant $\left.{ }^{-1}\right)$, capsule production, and corn yield. ${ }^{a}$

\begin{tabular}{|c|c|c|c|c|c|c|c|c|}
\hline \multirow[b]{2}{*}{ Year } & \multirow[b]{2}{*}{ Experiment } & \multirow[b]{2}{*}{ Effect } & \multirow[b]{2}{*}{$\mathrm{df}^{\mathrm{b}}$} & \multicolumn{5}{|c|}{$\mathrm{P}$ value } \\
\hline & & & & Mortality & Height & Biomass & Capsules & Yield \\
\hline \multirow[t]{2}{*}{2001} & Untreated & $\mathrm{Vd}$ & 4 & 0.0004 & 0.022 & 0.175 & 0.142 & 0.417 \\
\hline & & Herbicide by dose & 8 & 0.522 & 0.230 & 0.797 & 0.982 & 0.901 \\
\hline \multirow[t]{2}{*}{2002} & Untreated & $\mathrm{Vd}$ & 4 & 0.052 & 0.006 & 0.007 & 0.128 & 0.001 \\
\hline & Treated & Herbicide & 2 & 0.058 & 0.002 & 0.016 & 0.007 & 0.110 \\
\hline
\end{tabular}

${ }^{a}$ Abbreviations: Vd, initial velvetleaf density; $\mathrm{df}$, the numerator degrees of freedom.

${ }^{b}$ Denominator degrees of freedom were always 12 and 45 for the untreated and treated experiments, respectively. 
Reports of herbicide efficacy in the literature (70 to 100\%) are greater than the mortality observed here (Buhler et al. 1990; Niekamp and Johnson 2001). Herbicide efficacy is an estimate of the performance of a product based on visual estimates of weed biomass in treated plots relative to the biomass in an untreated check plot (Martin et al. 1998). Therefore, actual mortality is not reported. Data on herbicideinduced mortality are uncommon considering the amount of research published on weed management systems (Cousens and Mortimer 1995).

Velvetleaf Height. Pattern of velvetleaf height growth over time did not vary among density or herbicide treatments within a year, so we report only the results of maximum observed velvetleaf height in all treatments. Untreated velvetleaf was shorter in $2001(43 \mathrm{~cm})$ compared with 2002 $(162 \mathrm{~cm})$ (Figure 1). Velvetleaf height in both years decreased with initial density up to six plants per meter row, then remained constant at higher densities. Intraspecific competition among velvetleaf plants apparently resulted in a reduction of velvetleaf height. Competition with corn also may have a great influence on velvetleaf height. Murphy and Lindquist (2002) grew velvetleaf at 20 plants $\mathrm{m}^{-1}$ in monoculture and measured a maximum height of more than $220 \mathrm{~cm}$.

Herbicide-treated velvetleaf height in 2001 did not differ among herbicide or dose treatments (Table 2) and averaged 27 $( \pm 3.0) \mathrm{cm}$, which was similar to untreated velvetleaf at 20 plants $\mathrm{m}^{-1}$ row $(24 \mathrm{~cm}$; Figure 1$)$. Because corn (a $\mathrm{C}_{4}$ species) is expected to have greater water use efficiency than the $\mathrm{C}_{3}$ velvetleaf (Ehleringer and Monson 1993), competition from the crop may have severely affected velvetleaf growth in the dry conditions of 2001. Alternatively, velvetleaf height may have been affected adversely by pathogen infection, as discussed earlier.

Velvetleaf height in 2002 varied among herbicides and herbicide dose but not their interaction (Table 2). Velvetleaf across all herbicide doses was tallest in the flumiclorac $(107 \mathrm{~cm})$ and halosulfuron $(99 \mathrm{~cm})$ treatments and shortest in the dicamba treatment $(81 \mathrm{~cm})$. Velvetleaf height in 2002 declined with increasing herbicide dose (Figure 1). Herbicidetreated velvetleaf was shorter than untreated velvetleaf in all treatments except flumiclorac in the 0.1 - and 0.25 -dose treatments. Weed competition has the greatest detrimental effects on crop yield when allowed to compete with the crop during the critical period for weed control (e.g., Evans et al. 2003). Overshadowing of short plants by taller plants is the principal means by which plants compete for light. When weeds are controlled early in the season, shading by the crop will prevent subsequent weed competition for light. Therefore, suppressing velvetleaf height is critical for reducing its competitive effect on crops.

Velvetleaf Biomass. Untreated velvetleaf biomass in 2001 did not vary among density treatments and averaged $2.4 \pm 1.0 \mathrm{~g}$ plant $^{-1}$ (Figure 1). As with height in 2002, velvetleaf biomass plant $^{-1}$ declined sharply with increasing density up to six plants per meter row and remained constant thereafter. Although velvetleaf biomass per plant is smaller in the highdensity treatments, biomass per unit area increases with density and is expected to have the greatest negative impact on crop yield at high densities.

Herbicide-treated velvetleaf biomass in 2001 did not differ with herbicide type but did differ with dose (Table 2).
Biomass of plants in the recommended dose treatment was greater $\left(2.1 \mathrm{~g} \mathrm{plant}^{-1}\right)$ than at any other dose $\left(1.1 \mathrm{~g} \mathrm{plant}^{-1}\right)$. The reason for this is not clear but is of little biological importance because a 2 -g velvetleaf plant is unlikely to compete with corn.

Biomass of velvetleaf that survived herbicide treatment in 2002 varied with both herbicide and dose but not their interaction (Table 2). Velvetleaf biomass was similar in the dicamba $\left(9.3 \mathrm{~g} \mathrm{plant}^{-1}\right)$ and halosulfuron $\left(11.3 \mathrm{~g} \mathrm{plant}^{-1}\right)$ treatments but was greatest $\left(16.2 \mathrm{~g} \mathrm{plant}^{-1}\right)$ in the flumiclorac treatment. Biomass of treated velvetleaf in 2002 was generally smaller than that of untreated velvetleaf and decreased from $19 \mathrm{~g}$ plant ${ }^{-1}$ to about $8 \mathrm{~g} \mathrm{plant}^{-1}$ with increasing dose of all herbicides (Figure 1). This reduction in biomass is expected to result in less corn yield loss with increasing herbicide dose.

Seed Capsule Production. Untreated velvetleaf produced an average of 2.3 and 8.3 capsules plant $^{-1}$ in 2001 and 2002, respectively (Figure 1). Although untreated velvetleaf seed capsule production tended to decline with increasing density, these differences were not significant in either year (Table 2). The greatest production of 13 capsules plant ${ }^{-1}$ measured in this study was much lower than observed by Murphy and Lindquist (2002), who measured approximately 150 capsules plant $^{-1}$ for monoculture-grown velvetleaf at 20 plants $\mathrm{m}^{-1}$ row. These differences are likely the result of competition from the crop. Assuming that each velvetleaf seed capsule contains about 40 seeds (Lindquist et al. 1995), the number of seeds produced in $2002\left(\sim 500\right.$ seeds plant $\left.{ }^{-1}\right)$ was within the range reported by Clay et al. (2005).

Herbicide-treated velvetleaf capsule production was closely related to biomass accumulation in both years. Number of velvetleaf seed capsules produced in 2001 was similar for all herbicide treatments with a mean of 1.2 capsules plant ${ }^{-1}$. Number of velvetleaf seed capsules per plant in 2002 varied with herbicide and dose but not their interaction. Average number of capsules produced in 2002 (0.8 capsules plant ${ }^{-9}$ ) was smaller than in 2001.

Average capsule production in 2002 was similar for dicamba ( 0.4 capsules plant $\left.{ }^{-1}\right)$ and halosulfuron $(0.8$ capsules plant $\left.{ }^{-1}\right)$ but was greater $\left(1.3\right.$ capsules plant $\left.{ }^{-1}\right)$ in the flumiclorac treatments (Figure 1). Number of capsules produced declined with increasing dose for all herbicides. Even the lowest herbicide dose in 2002 reduced capsule production (0.9 to 3 capsules plant ${ }^{-1}$ ) compared with untreated velvetleaf (3.9 capsules plant ${ }^{-1}$ ) at 20 plants $\mathrm{m}^{-1}$ row.

Corn Yield. Corn yield did not vary with untreated velvetleaf density in 2001 (Table 2), and the overall mean yield was $494 \mathrm{~g} \mathrm{~m}^{-2}$. Mean weed-free yield was 2.5-fold greater $\left(1,237 \mathrm{~g} \mathrm{~m}^{-2}\right)$ in 2002 compared with 2001 , and yield declined with increasing untreated velvetleaf density (Figure 2). The very low yield and lack of response to velvetleaf interference in 2001 may be the result of severe drought combined with minimal velvetleaf height and biomass in that year.

Corn yield in 2001 was not influenced by herbicide or dose treatment (Table 2), and the mean yield of herbicide-treated corn was $495 \mathrm{~g} \mathrm{~m}^{-2}$. Corn yield in 2002 was generally greatest (overall mean $=1,049 \mathrm{~g} \mathrm{~m}^{-2}$ ) in the dicamba treatment compared with the halosulfuron $\left(931 \mathrm{~g} \mathrm{~m}^{-2}\right)$ and 

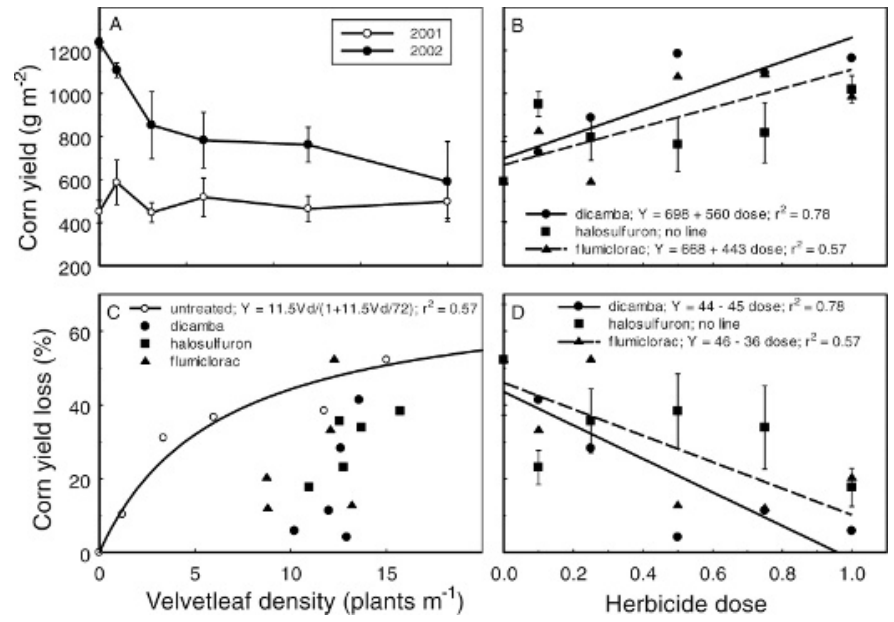

Figure 2. Corn yield and yield loss in response to initial velvetleaf density without herbicide treatment (left panels) and to three POST herbicides applied to 20 plants $\mathrm{m}^{-1}$ row at five doses (fraction of the labeled rate; right panels). Corn yield in 2001 and 2002 in relation to untreated velvetleaf density (panel A). Corn yield in 2002 in response to herbicide and dose (fraction of labeled rate; panel B). Corn yield loss in relation to untreated (open symbols) and herbicide-treated velvetleaf (closed symbols; panel C). Corn yield loss in response to herbicide and dose (panel D).

flumiclorac $\left(968 \mathrm{~g} \mathrm{~m}^{-2}\right)$ treatments. Except for the halosulfuron treatment, corn yield in the 0.5-, 0.75-, and 1.0-dose treatments generally did not differ from the weed-free yield, whereas yield in untreated and 0.25 -dose treatments were reduced by velvetleaf interference.

Corn Yield Loss. Owing to high-mortality rates and limited growth in 2001, velvetleaf interference did not reduce corn yield in any treatment (Table 2). Yield loss in 2002 resulting from untreated velvetleaf interference increased with velvetleaf density (Figure 2). Estimated yield loss as velvetleaf density approached zero was $11.5 \%$ in 2002 , which is similar to values for this location reported by Lindquist et al. (1996) but smaller than estimates reported by Lindquist and Mortensen (1998). Estimated maximum yield loss was $72 \%$ in 2002, which is within the range of values reported for velvetleaf (Lindquist and Mortensen 1998; Lindquist et al. 1996).

No yield loss was observed in any herbicide treatment in 2001 (Table 2). An herbicide-by-dose interaction effect on yield loss was observed in 2002. Corn yield loss declined with increasing dose of dicamba $\left(Y_{L}=37.4-36.9 \times\right.$ dose; $\mathrm{P}=$ $0.0004)$ and flumiclorac $\left(Y_{L}=41.6-29.8 \times\right.$ dose; $\mathrm{P}=$ 0.09 ) but not halosulfuron $(\mathrm{P}=0.55)$ (Figure 2). Corn yield loss in 2002 was lower than expected ( $P$ value for the chisquare test $=<0.0001)$ based on the untreated yield lossvelvetleaf density relationship (Equation 1) in all herbicide treatments except for the 0.1-dose dicamba treatment $(\mathrm{P}=$ $0.101)$.

Results show that velvetleaf surviving herbicide treatment in 2002 was not as competitive as an untreated plant, and competitiveness declined with increasing herbicide dose. Weeds subjected to herbicide treatment will be shorter, accumulate less biomass, and produce fewer seed than untreated plants. Injury to surviving velvetleaf resulting from herbicide treatment is as beneficial to the crop as highmortality rates. Crop plants will then be placed at a competitive advantage, with the chance to surpass weed growth; absorb more light, water, and nutrients; and produce more yield. Information about how weeds respond to reduced dose treatments can help to accurately calibrate DSS to account for reduced interference owing to herbicide injury. Reduced herbicide doses may allow growers to reduce input costs and achieve a satisfactory level of weed control without negative impacts on crop production.

\section{Sources of Materials}

${ }^{1}$ WeedSOFT, University of Nebraska-Lincoln, P.O. Box 830915, Lincoln NE 68583.

${ }^{2}$ Spraying Systems Co., Wheaton IL 60189-7900

3 SAS Institute Inc., 100 SAS Campus Dr., Cary NC 275132414.

\section{Acknowledgments}

This research is a contribution of the University of Nebraska Agricultural Research Division and was supported by the Cooperative State Research, Education, and Extension Service, U.S. Department of Agriculture, under Agreement 00-34103-9093 (North Central Regional IPM Grant), and by the State of Nebraska.

\section{Literature Cited}

Bridges, D. C. 1992. Crop losses due to weeds in the United States-1992. Lawrence, KS: Weed Science Society of America. 403 p.

Buhler, D. D., B. D. Philbrook, and E. S. Oplinger. 1990. Velvetleaf and giant foxtail control for solid-seeded soybean production in three tillage intensities. J. Prod. Agric. 3:302-308.

Clay, S. A., J. Kleinjan, D. E. Clay, F. Forcella, and W. Batchelor. 2005. Growth and fecundity of several weed species in corn and soybean. Agron. J. 97:294-302.

Cousens, R. 1985. A simple model relating yield loss to weed density. Ann. Appl. Biol. 107:239-252.

Cousens, R. and M. Mortimer. 1995. Dynamics of Weed Populations. Cambridge, UK: Cambridge University Press. Pp. 86-133.

DeFelice, M. S., W. B. Brown, R. J. Aldrich, B. D. Sims, D. T. Judy, and D. R. Guethle. 1989. Weed control in soybeans (Glycine max) with reduced rates of postemergence herbicides. Weed Sci. 37:365-374.

Devlin, D. L., J. H. Long, and L. D. Maddux. 1991. Using reduced rates of postemergence herbicides in soybeans. Weed Technol. 5:834-840.

Devore, J. and R. Peck. 1986. Statistics: The Exploration and Analysis of Data. St. Paul, MN: West Publishing. Pp. 639-640.

Dieleman, J. A., A. S. Hamill, G. C. Fox, and C. J. Swanton. 1996. Decision rules for postemergence control of pigweed (Amaranthus spp.) in soybean (Glycine max). Weed Sci. 44:126-132.

Dieleman, J. A. and D. A. Mortensen. 1998. Influence of weed biology and ecology on development of reduced dose strategies for integrated weed management systems. Pages 333-362 in J. L. Hatfield, D. D. Buhler, and B. A. Stewart, eds., Chelsea, MI: Ann Arbor Press.

Ehleringer, J. R. and R. K. Monson. 1993. Evolutionary and ecological aspects of photosynthetic pathway variation. Annu. Rev. Ecol. Syst. 24:411-439.

Evans, S. P., S. Z. Knezevic, J. L. Lindquist, C. A. Shapiro, and E. E. Blankenship. 2003. Nitrogen application influences the critical period for weed control in corn. Weed Sci. 51:408-417.

Hartzler, R. G. and B. A. Battles. 2001. Reduced fitness of velvetleaf (Abutilon theophrasti) surviving glyphosate. Weed Technol. 15:492-496.

Klirinomos, J. N. 2002. Feedback with soil biota contributes to plant rarity and invasiveness in communities. Nature 417:67-70.

Koide, R. T. and R. P. Schreiner. 1994. Alteration of leaf movement of Abutilon theophrasti (Malvaceae) by mycorrhizal infection. Funct. Ecol. 8:384-388.

Kremer, R. J. and L. K. Schulte. 1989. Influence of chemical treatment and Fusarium oxysporum on velvetleaf (Abutilon theophrasti). Weed Technol. 3:369-374.

Liebman, M., C. L. Mohler, and C. P. Staver. 2001. Ecological management of agricultural weeds. Pages 1-39 in Cambridge, UK: Cambridge University Press. 532 p.

Lindquist, J. L. and S. Z. Knezevic. 2001. Quantifying crop yield response to weed population: Applications and limitations. Pages 205-232 in R.K.D. 
Peterson and L. G. Higley, eds. Biotic Stress and Yield Loss. Boca Raton, FL: CRC Press.

Lindquist, J. L., B. D. Maxwell, D. D. Buhler, and J. L. Gunsolus. 1995. Velvetleaf (Abutilon theophrasti) recruitment, seed production, and interference in soybean (Glycine max). Weed. Sci. 43:226-232.

Lindquist, J. L., D. A. Mortensen, A. Clay, R. Schmenk, J. J. Kells, K. Howatt, and P. Westra. 1996. Stability of corn (Zea mays)-velvetleaf (Abutilon theophrasti) interference relationships. Weed Sci. 44:309-313.

Lindquist, J. L., D. A. Mortensen, and B. E. Johnson. 1998. Mechanisms of corn tolerance and velvetleaf suppressive ability. Agron. J. 90:787-792.

Liphadzi, K. B. and J. A. Dille. 2006. Annual weed competitiveness as affected by preemergence herbicide in corn. Weed Sci. 54:156-165.

Littell, R. C., G. A. Milliken, W. W. Stroup, and R. D. Wolfinger. 1996. SAS system for mixed models. Cary, NC: Statistical Analysis Systems Institute. 31 and $171 \mathrm{p}$.

Martin, A. R., D. A. Mortensen, and J. L. Lindquist. 1998. Decision support models for weed management: in-field management tools. Pages 363-369 in J L. Hatfield, D. D. Buhler, and B. A. Stewart, eds. Integrated Weed and Soil Management. Chelsea, MI: Ann Arbor Press.
Murphy, C. A. and J. L. Lindquist. 2002. Growth response of velvetleaf to three postemergence herbicides. Weed Sci. 50:364-369.

Neeser, C., J. T. Rawlinson, A. R. Martin, L. B. Bills, J. A. Dille, G. Krishnan, and D. A. Mortensen. 2004. WeedSOFT: a weed management decision support system. Weed Sci. 52:115-122.

Niekamp, J. W. and W. G. Johnson. 2001. Weed management with sulfentrazone and flumioxazin in no-tillage soybean (Glycine max). Crop Prot. 20:215-220.

Sattin, M., G. Zanin, and A. Berti. 1992. Case history for weed competition/ population ecology: velvetleaf (Abutilon theophrasti) in corn (Zea mays). Weed Technol. 6:213-219.

Sickinger, S. M., C. R. Grau, and R. G. Harvey. 1987. Verticillium wilt of velvetleaf (Abutilon theophrasti). Plant Dis. 71:415-418.

Warwick, S. I. and L. D. Black. 1988. The biology of Canadian weeds. 90. Abutilon theophrasti. Can. J. Plant. Sci. 68:1069-1085.

Received August 17, 2006, and approved May 3, 2007. 